\title{
Pengaruh Profitabilitas, Solvabilitas, dan Aktivitas Persediaan terhadap Audit Delay pada Perusahaan Retail yang terdaftar di Bursa Efek Indonesia Periode 2014-2015
}

\author{
Debbianita \\ Fakultas Ekonomi Program Studi Akuntansi-Univ.Kristen Maranatha \\ (Jl. Prof. Drg. Suria Sumantri No. 65, Bandung) \\ debbianita@gmail.com \\ Vinny Stephanie Hidayat \\ Fakultas Ekonomi Program Studi Akuntansi-Univ.Kristen Maranatha \\ (Jl. Prof. Drg. Suria Sumantri No. 65, Bandung) \\ vinny.tan@yahoo.co.id \\ Ivana \\ Fakultas Ekonomi Program Studi Akuntansi-Univ.Kristen Maranatha \\ (Jl. Prof. Drg. Suria Sumantri No. 65, Bandung) \\ suhardiivanna@gmail.com
}

\begin{abstract}
The aim of this research is to determine the effect of profitability, solvability, and inventory activity toward the Audit Delay on retail companies that are listed in Indonesia Stock Exchange. The population of this research is whole of the retail companies that are listed in the Indonesia Stock Exchange in 2014-2015. The method used in this research is explanatory research, and the sampling method used was judgement sampling method. Research hypothesis testing using $T$ test, $F$ test, and multiple regression analysis using SPSS version 20.0. The results show that profitability, solvability, and inventory activity have no effect on audit delay on retail companies that are listed in Indonesia Stock Exchange.
\end{abstract}

Keywords: Audit Delay, Inventory Activity, Profitability, and Solvability

\section{Pendahuluan}

Laporan keuangan merupakan sarana yang sangat penting dalam penyampaian kinerja keuangan suatu perusahaan. Laporan keuangan dapat digunakan sebagai informasi yang dapat membantu proses pengambilan keputusan dan kebijakan oleh para pihak yang berkepentingan seperti investor, kreditur, dan manajemen perusahaan itu sendiri. (Sinurat, 2014).

Ketepatan waktu yang merupakan salah satu dari karakteristik kualitatif laporan keuangan (karakteristik kualitatif relevan) merupakan hal yang sangat penting dalam penyajian laporan keuangan. Informasi suatu laporan keuangan dapat bermanfaat bagi para penggunanya apabila disajikan tepat waktu sehingga dapat berpengaruh dan berguna dalam pengambilan keputusan (Rizki M, 2014). Apabila suatu laporan keuangan tidak disajikan tepat waktu, maka laporan keuangan tersebut akan kehilangan relevansinya. Hal ini sesuai dengan PSAK No. 1 paragraf 43, yaitu bahwa jika terdapat penundaan yang tidak semestinya dalam pelaporan, maka informasi yang dihasilkan akan kehilangan relevansinya. Dengan demikian, informasi yang memiliki prediksi tinggi dapat menjadi tidak relevan apabila tidak tersedia pada saat dibutuhkan (Agustina \& Aldie, 2013).

Ketepatan waktu (timeliness) dalam penyampaian laporan keuangan telah diatur dalam pasar modal (Setyaningsih, 2014). Pada tahun 1996, Badan Pengawas Pasar Modal (BAPEPAM) mengeluarkan Lampiran Keputusan Ketua Bapepam No. KEP-80/PM/1996 yang berisi bahwa setiap emiten dan perusahaan wajib untuk menyampaikan laporan keuangan tahunan perusahaan dan laporan keuangan yang telah diaudit oleh akuntan publik kepada Badan Pengawas Pasar Modal (BAPEPAM) selambat-lambatnya 120 hari setelah tanggal laporan 
keuangan tahunan perusahaan. Akan tetapi, keputusan tesebut telah diubah dan diperketat lagi sesuai dengan Lampiran Keputusan Ketua BAPEPAM No. KEP-36/PM/2003 tanggal 30 September 2003 mengenai kewajiban penyampaian laporan keuangan berkala yang menyatakan bahwa laporan keuangan tahunan harus disertai laporan akuntan dengan pendapat yang lazim dan disampaikan kepada Badan Pengawas Pasar Modal (BAPEPAM) selambat-lambatnya pada akhir bulan ketiga setelah tanggal laporan keuangan tahunan (Setyaningsih, 2014). Apabila perusahaan-perusahaan go public tersebut terlambat menyampaikan laporan sesuai dengan ketentuan yang telah ditetapkan oleh Badan Pengawas Pasar Modal (BAPEPAM), maka perusahaan-perusahaan tersebut akan dikenakan sanksi sesuai dengan Ketentuan II.6.1. Peraturan Nomor I-H: Tentang Sanksi, Bursa akan memberikan Peringatan Tertulis I atas keterlambatan penyampaian Laporan Keuangan sampai 30 (tiga puluh) hari kalender terhitung sejak lampaunya batas waktu penyampaian Laporan Keuangan (Setyaningsih, 2014).

Audit delay merupakan lamanya/ rentang waktu penyelesaian audit yang diukur dari tanggal penutupan tahun buku sampai dengan tanggal diterbitkannya laporan audit. Audit delay inilah yang dapat mempengaruhi ketepatan informasi yang dipublikasikan, sehingga akan berpengaruh terhadap tingkat ketidakpastian keputusan yang berdasarkan informasi yang dipublikasikan (Kartika, 2009).

Terdapat beberapa faktor yang mempengaruhi Audit delay, diantaranya adalah profitabilitas, solvabilitas, dan aktivitas persediaan perusahaan. Menurut Wirakusuma (2004) dalam Lianto \& Kusuma (2010), profitabilitas merupakan kemampuan perusahaan memanfaatkan aset yang ada untuk menghasilkan pendapatan. Variabel ini diproksi melalui Return On Assets. Profitabilitas menunjukkan keberhasilan perusahaan dalam menghasilkan keuntungan. Perusahaan yang memiliki tingkat profitabilitas yang lebih tinggi membutuhkan waktu yang lebih cepat dalam pengauditan laporan keuangan dikarenakan keharusan untuk menyampaikan kabar baik secepatnya kepada publik (Lianto \& Kusuma, 2010). Hal tersebut sesuai dengan hasil penelitian yang dilakukan oleh Simbolon (2009) yang menyatakan bahwa kenaikan profitabilitas berpengaruh terhadap Audit delay karena profitabilitas yang tinggi menunjukkan seberapa besar keuntungan yang diperoleh sehingga Audit delay akan lebih singkat sebab perusahaan ingin lebih cepat menyampaikan kabar baik tersebut kepada para pemegang sahamnya. Namun hal tersebut bertentangan dengan penelitian yang dilakukan oleh Susilawati, Agustina \& Prameswari (2012) yang menyatakan bahwa profitabilitas tidak berpengaruh terhadap Audit delay. Hal ini disebabkan banyak perusahaan yang mengalami kenaikan profit namun kenaikan itu tidak begitu besar, apalagi terdapat perusahaan yang mengalami kerugian. Selain itu mungkin tuntutan pihak-pihak yang berkepentingan tidak begitu besar sehingga tidak memicu perusahaan untuk mengkomunikasikan laporan keuangan yang diaudit lebih cepat.

Menurut Almilia \& Setiady (2006) dalam Setyaningsih (2014), solvabilitas adalah kemampuan perusahaan dalam membayar semua kewajibannya (baik kewajiban jangka panjang maupun jangka pendek) dari harta perusahaan tersebut. Solvabilitas dalam penelitian ini diproksi oleh rasio Debt to Equity (DER). Carslaw dan Kaplan (1991) dalam Rachmawati (2008) dalam Lianto \& Kusuma (2014) mengungkapkan bahwa tingginya proporsi dari hutang akan meningkatkan pula resiko keuangan suatu perusahaan. Oleh karena itu perusahaan yang memiliki kondisi keuangan yang tidak sehat cenderung dapat melakukan mismanagement dan fraud. Hal ini pada akhirnya memerlukan kecermatan yang lebih dalam dalam pengauditan. Namun hal tersebut bertentangan dengan hasil penelitian yang dilakukan oleh Yuliyanti (2011) yang menyatakan bahwa solvabilitas tidak berpengaruh terhadap Audit delay. Hal ini dikarenakan baik perusahaan yang memiliki total utang besar dengan jumlah debtholder yang banyak atau perusahaan yang memiliki total hutang yang kecil dengan jumlah debtholder yang sedikit tidak akan mempengaruhi proses penyelesaian audit laporan keuangan, karena auditor yang ditunjuk pasti telah menyediakan waktu sesuai dengan kebutuhan jangka waktu untuk menyelesaikan proses pengauditan utang (Trianto (2006) dalam Yuliyanti, (2011)).

Perputaran Persediaan merupakan bagian daripada rasio aktivitas. Aktivitas persediaan dalam penelitian ini diproksikan dalam rasio Inventory Turnover (IO). Menurut Soemarso (2004) dalam Kusuma, Arifati, \& Andini (2014), perputaran persediaan menunjukkan berapa kali (secara rata-rata) persediaan barang dijual dan diganti selama satu periode. Dengan adanya pengelolaan persediaan yang baik, perusahaan dapat dengan segera mengubah persediaan yang tersimpan menjadi laba melalui penjualan (Hafis, 2016). Raharjaputra (2009) dalam Hafis (2016) menyatakan bahwa semakin tinggi tingkat perputaran persediaan, kemungkinan semakin besar perusahaan akan memperoleh keuntungan, begitu pula sebaliknya, jika tingkat perputaran persediaannya rendah maka kemungkinan semakin kecil perusahaan akan memperoleh keuntungan. Namun hal tersebut bertentangan dengan hasil penelitian Ramadhan (2012) yang menyatakan bahwa rasio aktivitas tidak berpengaruh terhadap .Audit delay, dikarenakan perusahaan belum mampu memutar aktivanya secara efektif. 


\section{Kerangka Pemikiran dan Hipotesis}

\section{Pengaruh Profitabilitas terhadap Audit Delay}

Menurut Wirakusuma (2004) dalam Lianto \& Kusuma (2010), profitabilitas merupakan kemampuan perusahaan memanfaatkan aset yang ada untuk menghasilkan pendapatan. Variabel ini diproksi melalui Return On Assets, yang diukur dari laba bersih setelah pajak dibagi dengan total aktiva. Profitabilitas menunjukkan keberhasilan perusahaan dalam menghasilkan keuntungan. Dengan demikian dapat dikatakan bahwa profit merupakan berita baik bagi perusahaan. Perusahaan tidak akan menunda penyampaian informasi yang berisi berita baik. Perusahaan yang memiliki tingkat profitabilitas yang lebih tinggi membutuhkan waktu yang lebih cepat dalam pengauditan laporan keuangan dikarenakan keharusan untuk menyampaikan kabar baik secepatnya kepada publik (Lianto \& Kusuma, 2010). Hal tersebut sesuai dengan hasil penelitian yang dilakukan oleh Simbolon (2009) yang menyatakan bahwa kenaikan profitabilitas berpengaruh terhadap Audit delay karena profitabilitas yang tinggi menunjukkan seberapa besar keuntungan yang diperoleh sehingga Audit delay akan lebih singkat sebab perusahaan ingin lebih cepat menyampaikan kabar baik tersebut kepada para pemegang sahamnya. Namun hal tersebut bertentangan dengan penelitian yang dilakukan oleh, Susilawati, Agustina \& Prameswari (2012) yang menyatakan bahwa profitabilitas tidak berpengaruh terhadap Audit delay. Hal ini disebabkan banyak perusahaan yang mengalami kenaikan profit namun kenaikan itu tidak begitu besar, apalagi terdapat perusahaan yang mengalami kerugian. Selain itu mungkin tuntutan pihak-pihak yang berkepentingan tidak begitu besar sehingga tidak memicu perusahaan untuk mengkomunikasikan laporan keuangan yang diaudit lebih cepat.

\section{Pengaruh Solvabilitas terhadap Audit Delay}

Menurut Almilia \& Setiady (2006) dalam Setyaningsih (2014), solvabilitas adalah kemampuan perusahaan dalam membayar semua kewajibannya (baik kewajiban jangka panjang maupun jangka pendek) dari harta perusahaan tersebut. Solvabilitas dalam penelitian ini diproksi oleh rasio Debt to Equity (DER). Carslaw dan Kaplan (1991) dalam Rachmawati (2008) dalam Lianto \& Kusuma (2014) mengungkapkan bahwa tingginya proporsi dari hutang akan meningkatkan pula resiko keuangan suatu perusahaan. Oleh karena itu perusahaan yang memiliki kondisi keuangan yang tidak sehat cenderung dapat melakukan mismanagement dan fraud. Hal ini pada akhirnya memerlukan kecermatan yang lebih dalam dalam pengauditan. Namun hal tersebut bertentangan dengan hasil penelitian yang dilakukan oleh Yuliyanti (2011) yang menyatakan bahwa solvabilitas tidak berpengaruh terhadap Audit delay. Hal ini dikarenakan baik perusahaan yang memiliki total utang besar dengan jumlah debtholder yang banyak atau perusahaan yang memiliki total hutang yang kecil dengan jumlah debtholder yang sedikit tidak akan mempengaruhi proses penyelesaian audit laporan keuangan, karena auditor yang ditunjuk pasti telah menyediakan waktu sesuai dengan kebutuhan jangka waktu untuk menyelesaikan proses pengauditan utang (Trianto (2006) dalam Yuliyanti, (2011)).

\section{Pengaruh Aktivitas Persediaan terhadap Audit Delay}

Perputaran Persediaan merupakan bagian daripada rasio aktivitas. Halim (2007) dalam Kamaliah, Akbar, \& Kinanti (2009) mengemukakan bahwa rasio aktivitas digunakan untuk mengukur sampai seberapa besar efektivitas perusahaan dalam menggunakan sumber dayanya yang berupa aset. Aktivitas persediaan dalam penelitian ini diproksikan dalam rasio Inventory Turnover $(I O)$. Menurut Soemarso (2004) dalam Kusuma, Arifati, \& Andini (2014), perputaran persediaan menunjukkan berapa kali (secara rata-rata) persediaan barang dijual dan diganti selama satu periode. Penetapan nilai persediaan memang memiliki peran yang sangat penting dalam proses mempertemukan pendapatan dan biaya dalam satu periode (Hafis, 2016). Dengan adanya pengelolaan persediaan yang baik, perusahaan dapat dengan segera mengubah persediaan yang tersimpan menjadi laba melalui penjualan (Hafis, 2016). Pengelolaan persediaan merupakan suatu pekerjaan yang sulit, dimana kesalahan dalam menentukan tingkat persediaan dapat berakibat fatal (Hafis, 2016). Raharjaputra (2009) dalam Hafis (2016) menyatakan bahwa semakin tinggi tingkat perputaran persediaan, kemungkinan semakin besar perusahaan akan memperoleh keuntungan, begitu pula sebaliknya, jika tingkat perputaran persediaannya rendah maka kemungkinan semakin kecil perusahaan akan memperoleh keuntungan. Namun hal tersebut bertentangan dengan hasil penelitian Ramadhan (2012) yang menyatakan bahwa rasio aktivitas tidak berpengaruh terhadap Audit delay, dikarenakan perusahaan belum mampu memutar aktivanya secara efektif.

\section{Hipotesis}

$\mathrm{H}_{1}$ : Profitabilitas berpengaruh terhadap Audit Delay pada perusahaan Retail yang terdaftar di Bursa Efek Indonesia tahun 2014-2015.

$\mathrm{H}_{2}$ : Solvabilitas berpengaruh terhadap Audit Delay pada perusahaan Retail yang terdaftar di Bursa Efek Indonesia tahun 2014-2015.

$\mathrm{H}_{3}$ : Aktivitas Persediaan berpengaruh terhadap Audit Delay pada perusahaan Retail yang 
terdaftar di Bursa Efek Indonesia tahun 2014-2015..

$\mathrm{H}_{4}$ : Profitabilitas, Solvabilitas, dan Aktivitas Persediaan secara bersama-sama berpengaruh terhadap Audit Delay pada perusahaan Retail yang terdaftar di Bursa Efek Indonesia tahun 2014-2015.

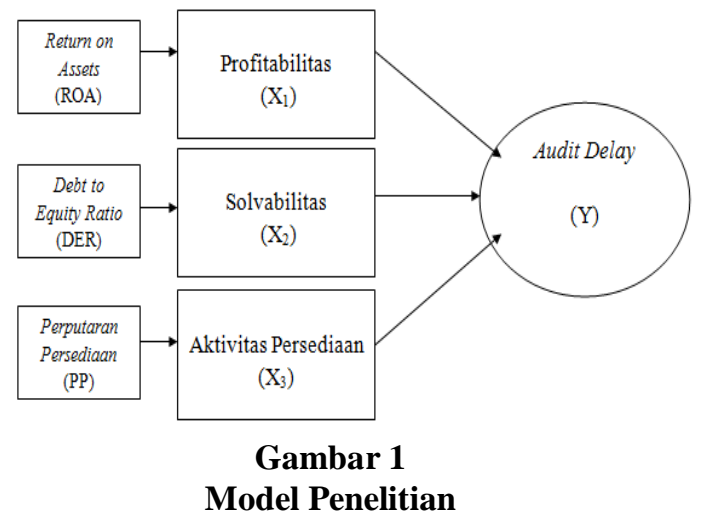

\section{Kerangka Teoritis}

\section{Teori Kepatuhan (Compliance Theory)}

Menurut Tyler dalam Dewi (2013) dalam Pratama (2014) terdapat dua persepektif dasar mengenai kepatuhan hukum dalam teori kepatuhan yaitu instrumental dan normatif. Perspektif instrumental mengasumsikan individu secara utuh didorong oleh kepentingan pribadi dan tanggapan-tanggapan terhadap perubahan insentif dan penalti yang berhubungan dengan prilaku. Perspektif normatif berhubungan dengan apa yang orang anggap sebagai moral dan berlawanan dengan kepentingan pribadi mereka.

Tuntutan akan kepatuhan terhadap ketepatan waktu dalam penyampaian laporan keuangan tahunan perusahaan publik di Indonesia telah diatur dalam keputusan ketua BAPEPAM Nomor: KEP346/BL/2011 tentang kewajiban penyampaian laporan keuangan berkala. Peraturan-peraturan tersebut secara hukum mengisyaratkan adanya kepatuhan setiap perilaku individu maupun organisasi (perusahaan publik) yang terlibat di pasar modal Indonesia untuk menyampaikan laporan keuangan tahunan secara tepat waktu (Pratama, 2014).

\section{Audit Delay}

Audit delay merupakan lamanya atau rentang waktu penyelesaian audit yang diukur dari tanggal penutupan tahun buku sampai dengan tanggal diterbitkannya laporan audit (Halim (2000) dalam Purnamasari (2012)). Diungkap dalam penelitian Subekti \& Widiyanti (2004) dalam Purnamasari (2012), perbedaan waktu yang sering dinamakan dengan audit delay adalah perbedaan antara tanggal laporan keuangan dengan tanggal opini audit dalam laporan keuangan yang mengindikasikan tentang lamanya waktu penyelesaian audit yang dilakukan oleh auditor.

Dyer dan Mc Hugh dalam Hilmi \& Ali (2008) dalam Purnamasari (2012) menggunakan tiga kriteria keterlambatan untuk melihat ketepatan waktu dalam penelitiannya, yakni:

1. Preliminary lag : interval jumlah hari antara tanggal laporan keuangan sampai penerimaan laporan akhir preliminary oleh bursa.

2. Auditor's report lag : interval jumlah hari antara tanggal laporan keuangan sampai tanggal laporan auditor ditandatangani.

3. Total lag : interval jumlah hari antara tanggal laporan keuangan sampai tanggal penerimaan laporan dipublikasikan oleh bursa.

Audit delay inilah yang dapat mempengaruhi ketepatan informasi yang dipublikasikan, sehingga akan berpengaruh terhadap tingkat ketidakpastian keputusan yang berdasarkan informasi yang dipublikasikan (Kartika (2009) dalam Purnamasari (2012)).

Ketepatan waktu penyusunan atau pelaporan suatu laporan keuangan perusahaan bisa berpengaruh pada nilai laporan keuangan tersebut. Keterlambatan informasi akan menimbulkan reaksi negatif dari pelaku pasar modal. Informasi laba yang dihasilkan perusahaan dijadikan sebagai salah satu dasar pengambilan keputusan untuk membeli atau menjual kepemilikan yang dimiliki oleh investor. Artinya, informasi yang dipublikasikan tersebut akan menyebabkan kenaikan atau penurunan harga saham (Purnamasari, 2012).

\section{Profitabilitas}

Menurut Wirakusuma (2004) dalam Lianto \& Kusuma (2010), profitabilitas merupakan kemampuan perusahaan memanfaatkan aset yang ada untuk menghasilkan pendapatan.

Menurut Almilia \& Setiady (2006) dalam Setyaningsih (2014), profitabilitas adalah kemampuan perusahaan untuk menghasilkan keuntungan pada tingkat penjualan, aset, dan modal saham tertentu. Menurut Hassanudin dalam Utami (2006) dalam Setyaningsih (2014), laba menunjukkan keberhasilan perusahaan dalam menghasilkan keuntungan, sehingga dapat dikatakan bahwa laba merupakan berita baik. Profitabilitas suatu perusahaan mencerminkan tingkat efektivitas yang dicapai oleh suatu operasional perusahaan.

Menurut Wild, dkk. (2005) dalam Setyaningsih (2014), Return on Asset (ROA) adalah perbandingan antara laba sebelum pajak dan total aset. Dalam penelitian ini profitabilitas diukur dengan menggunakan Return on Asset (ROA) dengan rumus sebagai berikut:

Return on Asset $=\frac{\text { Laba Sebelum Pajak }}{\text { Total Aset }} \times 100 \%$ 


\section{Solvabilitas}

Rasio solvabilitas merupakan rasio yang digunakan untuk mengukur sejauh mana aktiva perusahaan dibiayai dengan utang (Kasmir (2014) dalam Fitriana, Andini, \& Oemar (2016)). Artinya, seberapa besar beban utang yang ditanggung perusahaan dibandingkan dengan aktivanya (Kasmir (2014) dalam Fitriana, Andini, \& Oemar (2016)). Rasio ini untuk digunakan untuk mengukur kemampuan perusahaan memenuhi kewajiban-kewajiban jangka panjangnya (Munawir (2001) dalam Fitriana, Andini, \& Oemar (2016)). Dalam penelitian ini, rasio yang akan dipakai adalah Debt to Equity Ratio (DER). Menurut Wild, Subramanyam, \& Halsey (2005) dalam Simbolon (2009), DER dapat dihitung dengan rumus sebagai berikut:

Debt to Equity Ratio $=\frac{\text { Total Kewajiban }}{\text { Total Ekuitas }} \times 100 \%$

\section{Aktivitas Persediaan}

Halim (2007) dalam Kamaliah, Akbar, \& Kinanti (2009) mengemukakan bahwa rasio aktivitas digunakan untuk mengukur sampai seberapa besar efektivitas perusahaan dalam menggunakan sumber dayanya yang berupa aset.

Menurut Sawir (2005) dalam Kamaliah, \& Akbar, \& Kinanti (2009) rasio ini menunjukkan efektivitas penggunaan seluruh harta perusahaan dalam rangka menghasilkan penjualan atau menggambarkan berapa rupiah penjualan bersih yang dapat dihasilkan oleh setiap rupiah yang diinvestasikan dalam bentuk harta perusahaan.

Menurut Kasmir (2008) dalam Hafis (2016), perputaran persediaan merupakan rasio yang digunakan untuk mengukur berapa kali dana yang ditanam dalam sediaan (inventory) ini berputar dalam satu periode. Dapat diartikan pula bahwa perputaran sediaan merupakan rasio yang menunjukkan berapa kali jumlah barang sediaan diganti dalam satu tahun. Menurut Harmono (2009) dalam Hafis (2016) perputaran persediaan merupakan sejauh mana persediaan dalam satu tahun dapat diperoleh dari harga pokok penjualan dbagi saldo rata-rata persediaan.

Syamsuddin (2011) dalam Hafis (2016) juga menambahkan untuk menghitung

perputaran persediaan dan menghitung umur rata-rata persediaan adalah:

$$
\text { Inventory Turnover }=\frac{\text { Cost of Goods Sold }}{\text { Average Inventory }}
$$

\section{Penelitian Terdahulu}

Terdapat beberapa penelitian sebelumnya yang melakukan penelitian tentang rasio keuangan yang mempengaruhi Audit Delay.

Simbolon (2009) melakukan penelitian mengenai Analisis Faktor-Faktor yang mempengaruhi Audit Delay pada Perusahaan yang terdaftar di Bursa Efek Indonesia. Penelitian ini menggunakan Audit
Delay sebagai variabel dependen, dan sebagai variabel independennya adalah Return On Assets (ROA), Debt to Equity Ratio (DER), Total Aktiva, serta reputasi Kantor Akuntan Publik. Metode analisis yang digunakan adalah regresi berganda. Sampel penelitian ini adalah 199 perusahaan yang terdaftar di Bursa Efek Indonesia periode tahun 2005-2007. Simpulan dari penelitian ini bahwa secara simultan Return On Assets (ROA), Debt to Equity Ratio (DER), Total Aktiva, serta reputasi Kantor Akuntan Publik berpengaruh negatif signifikan terhadap Audit Delay. Secara parsial, ROA berpengaruh negatif signifikan terhadap Audit Delay, sedangkan Debt to Equity Ratio (DER), Total Aktiva, serta reputasi Kantor Akuntan Publik tidak berpengaruh terhadap terhadap Audit Delay.

Susilawati, Agustina \& Prameswari (2012) melakukan penelitian mengenai Analisis FaktorFaktor yang mempengaruhi terjadinya Audit Delay pada Perusahaan Consumer Good Industry di Bursa Efek Indonesia (Periode Tahun 2008-2010). Penelitian ini menggunakan Audit Delay sebagai variabel dependen, dan sebagai variabel independennya adalah Profitabilitas (ROA), Solvabilitas (DER), Perusahaan Holding, Opini Auditor, dan lamanya perusahaan menjadi klien Kantor Akuntan Publik (KAP). Metode analisis yang digunakan adalah regresi berganda. Sampel penelitian ini adalah 93 laporan keuangan perusahaan consumer good industry yang terdaftar di Bursa Efek Indonesia periode tahun 2008-2010. Simpulan dari penelitian ini bahwa secara simultan seluruh variabel independen berpengaruh terhadap Audit Delay. Secara parsial, profitabilitas tidak berpengaruh terhadap Audit Delay, sedangkan solvabilitas dan perusahaan holding berpengaruh terhadap Audit Delay, serta opini auditor tidak berpengaruh signifikan terhadap terhadap Audit Delay.

Lianto \& Kusuma (2010) melakukan penelitian mengenai Faktor-Faktor yang berpengaruh pada Audit Report Lag. Penelitian ini menggunakan Audit Report Lag sebagai variabel dependen, dan sebagai variabel independennya adalah Profitabilitas (return on assets), Solvabilitas (total debt to total assets), Ukuran Perusahaan (jumlah total aktiva), Umur Perusahaan, dan Jenis Industri. Metode analisis yang digunakan adalah regresi berganda. Sampel penelitian ini adalah 28 perusahaan consumer goods industry dan 11 perusahaan multifinance yang terdaftar di Bursa Efek Indonesia periode tahun 20042008. Simpulan dari penelitian ini bahwa secara simultan Return On Assets (ROA), Debt to Equity Ratio (DER), Total Aktiva, serta reputasi Kantor Akuntan Publik berpengaruh negatif signifikan terhadap Audit Delay. Secara parsial, profitabilitas, solvabilitas, umur perusahaan berpengaruh terhadap Audit Report Lag. Sedangkan ukuran perusahaan dan jenis industri tidak berpengaruh terhadap Audit Report Lag 
Yuliyanti (2011) melakukan penelitian mengenai Faktor-faktor yang Berpengaruh terhadap Audit Delay (Studi Empiris pada Perusahaan Manufaktur yang terdaftar di Bursa Efek Indonesia pada Tahun 2007-2008). Penelitian ini menggunakan Audit Delay sebagai variabel dependen, dan sebagai variabel independennya adalah ukuran perusahaan, opini auditor, ukuran KAP, solvabilitas, dan profitabilitas. Metode analisis yang digunakan adalah regresi berganda. Sampel penelitian ini adalah 63 perusahaan manufaktur yang terdaftar di Bursa Efek Indonesia periode tahun 2007-2008. Simpulan dari penelitian ini bahwa secara simultan seluruh variabel independen berpengaruh terhadap Audit Delay. Secara parsial, ukuran perusahaan dan ukuran KAP berpengaruh terhadap Audit Delay. Sedangkan opini auditor, solvabilitas, dan profitabilitas tidak berpengaruh terhadap Audit Delay.

Hafis (2016) melakukan penelitian mengenai Pengaruh Perputaran Persediaan dan Perputaran Piutang terhadap Profitabilitas pada PT Kimia Farma Persero (Tbk). Penelitian ini menggunakan profitabilitas sebagai variabel dependen, dan sebagai variabel independennya adalah perputaran persediaan dan perputaran piutang. Metode analisis yang digunakan adalah regresi berganda. Simpulan dari penelitian ini bahwa perputaran persediaan dan perputaran piutang mempunyai pengaruh positif terhadap return on investment.

Ramadhan (2012) melakukan penelitian mengenai Analisis Faktor-Faktor yang mempengaruhi Audit Delay (Studi Empiris pada Perusahaan Manufaktur yang Terdaftar di Daftar Efek Syariah Tahun 2008-2010). Penelitian ini menggunakan Audit delay sebagai variabel dependen, dan sebagai variabel independennya adalah profitabilitas, likuiditas, rasio aktivitas, ukuran perusahaan, dan kualitas Kantor Akuntan Publik. Metode analisis yang digunakan adalah regresi berganda. Sampel penelitian ini adalah 201 perusahaan manufaktur yang terdaftar di Daftar Efek Syariah periode tahun 2008-2010. Simpulan dari penelitian ini bahwa secara simultan seluruh variabel independen berpengaruh terhadap laba Audit delay. Secara parsial, hanya profitabilitas yang berpengaruh secara negatif dan signifikan terhadap Audit delay.

\section{Metode Penelitian}

\section{Populasi dan Teknik Pengambilan Sampel}

Objek penelitian yang digunakan dalam penelitian ini adalah Laporan Keuangan perusahaan-perusahaan retail yang terdaftar di Bursa Efek Indonesia periode tahun 2014-2015. Peneliti akan menganalisis mengenai Audit Delay, dimana penelitian akan dilakukan untuk meneliti apakah Audit Delay dapat dipengaruhi oleh Profitabilitas (ROA), Solvabilitas (DER), dan Perputaran Persediaan (PP). Alasan peneliti mengambil perusahaan sub sektor perdagangan eceran (retail) karena perusahaan retail merupakan perusahaan yang cukup dikenal oleh masyarakat luas.

Penelitian ini menggunakan purposive sampling berupa judgement sampling.

Purposive sampling merupakan pemilihan sampel secara tidak acak yang informasinya diperoleh dengan menggunakan pertimbangan tertentu disesuaikan dengan tujuan atau masalah penelitian. Alasan penggunaan metode purposive sampling didasari pertimbangan agar sampel data yang dipilih memenuhi kriteria untuk diuji (Indriantoro \& Supomo (1999) dalam Yuliyanti (2011)). Judgement sampling (purposive sampling) adalah teknik penarikan sampel yang dilakukan berdasarkan karakteristik yang ditetapkan terhadap elemen populasi target yang disesuaikan dengan tujuan atau masalah penelitian (Maharani, 2015).

Adapun kriteria pengambilan sampel untuk perusahaan perdagangan eceran (retail) yang terdaftar di Bursa Efek Indonesia yang akan digunakan di penelitian ini adalah sebagai berikut:

1. Perusahaan retail yang terdaftar di Bursa Efek Indonesia.

2. Menyediakan laporan keuangan yang telah diaudit dari tahun 2014-2015

\section{Jenis dan Sumber Data}

Data yang digunakan dalam penelitian ini adalah data sekunder atau sumber sekunder. Data sekunder merupakan sumber data yang diperoleh peneliti secara tidak langsung melalui media perantara. Data sekunder pada umumnya berupa bukti, catatan, atau laporan historis yang telah tersusun dalam arsip, baik yang dipublikasikan dan yang tidak dipublikasikan. Manfaat dari data sekunder adalah lebih meminimalkan biaya dan waktu, mengklasifikasikan permasalahan-permasalahan, menciptakan tolak ukur untuk mengevaluasi data primer, dan memenuhi kesenjangan-kesenjangan informasi. Jika informasi telah ada, pengeluaran uang dan pengorbanan waktu dapat dihindari dengan menggunakan data sekunder. Manfaat lain dari data sekunder adalah bahwa seorang peneliti mampu memperoleh informasi lain selain informasi utama (Accounting Media, 2014). Jenis data sekunder yang digunakan penelitian ini berupa Debt to Equity Ratio (DER), Return on Assets ROA), Perputaran Persediaan (PP) dan Audit Delay, yang didapatkan dari laporan keuangan perusahaan retail yang terdaftar di Bursa Efek Indonesia periode tahun 2014-2015.

\section{Metode Penelitian}

Penelitian ini merupakan explanatory research. Menurut Umar (1999) dalam Wijaya (2013), penelitian eksplanatori (explanatory research) adalah 
penelitian yang bertujuan untuk menganalisis hubungan-hubungan antara satu variabel dengan variabel lainnya atau bagaimana suatu variabel mempengaruhi variabel lainnya.

\section{Teknik Pengumpulan Data}

Teknik pengumpulan data dalam penelitian ini adalah studi dokumen. Studi dokumen adalah metode pengumpulan data yang tidak ditujukan langsung kepada subjek penelitian. Studi dokumen adalah jenis pengumpulan data yang meneliti berbagai macam dokumen yang berguna untuk bahan analisis (UCEO, 2016). Dokumen yang digunakan berupa laporan keuangan perusahaan-perusahaan retail yang terdaftar di Bursa Efek Indonesia periode 2014-2015, Peneliti mengumpulkan data dari data base Bursa Efek Indonesia.

\section{Teknik Analisis \\ Uji Asumsi Klasik \\ Uji Normalitas}

Uji normalitas bertujuan untuk menguji apakah dalam model regresi, variabel pengganggu atau residual memiliki distribusi normal (Ghozali (2005) dalam Agustina \& Aldie 2013)). Model regresi yang paling baik memiliki distribusi data normal atau mendekati normal. Normalitas dapat dideteksi dengan alat analisis grafik berupa PP Plot dan uji Kolmogorov Smirnov dengan melihat penyebaran data pada sumbu diagonal dari grafik atau dengan melihat histogram dari nilai signifikan residualnya. Jika data menyebar disekitar garis diagonal dan mengikuti arah garis diagonal atau grafik histogramnya menunjukkan pola distribusi normal, maka model regresi memenuhi asumsi normalitas. Pedoman pengambilan keputusan yaitu:

Apabila nilai signifikasi atau probabilitas $>0,05$, maka distribusi data normal.

Apabila nilai signifikasi atau probabilitas $<0,05$, maka distribusi data tidak normal (Agustina \& Aldie, 2013).

\section{Uji Multikolinearitas}

Menurut Ghozali (2011) dalam Ahmad, Murni, \& Mandagie (2014), uji multikolinearitas bertujuan untuk menguji apakah model regresi ditemukan adanya korelasi antar variabel bebas (independen). Model regresi yang baik adalah tidak terjadi korelasi diantara variabel independen. Multikolinearitas dapat dilihat dari nilai tolerance dan lawannya yaitu Variance Inflation Factor (VIF). Untuk pengambilan keputusan dalam menentukan ada atau tidaknya multikolinearitas yaitu dengan kriteria sebagai berikut:

- Jika nilai VIF > 10 atau jika nilai tolerance < 0,1 maka ada multikolinearitas dalam model regresi.
- Jika nilai VIF < 10 atau jika nilai tolerance > 0,1 maka tidak ada multikolinearitas dalam model regresi .

\section{Uji Autokorelasi}

Pengujian ada atau tidaknya autokorelasi, penelitian ini menggunakan uji Durbin-Watson. Pengambilan keputusan ada atau tidaknya autokorelasi yaitu jika 0 $<\mathrm{d}<\mathrm{dl}=$ Ada autokorelasi $\mathrm{dl} \leq \mathrm{d} \leq \mathrm{du}=$ Tidak ada kesimpulan $4-\mathrm{dl}<\mathrm{d}<4=$ Ada autokorelasi $4-\mathrm{du} \leq$ $\mathrm{d} \leq 4-\mathrm{dl}=$ Tidak ada kesimpulan $\mathrm{du}<\mathrm{d}<4-\mathrm{du}=$ Tidak ada autokorelasi (Ghozali (2011) dalam Ahmad, Murni, \& Mandagie (2014))

\section{Uji Heteroskedastisitas}

Uji Glejser adalah uji hipotesis untuk mengetahui apakah sebuah model regresi memiliki indikasi heterokedastisitas dengan cara meregres absolud residual (UbsUt). Heteroskedastisitas adalah salah satu asumsi klasik sebagai prasyarat melakukan analisis regresi. Tes heteroskedastisitas bisa dilihat berdasarkan scatterplot.

Tetapi tes heteroskedastisitas menggunakan scatterplot sangat lemah karena hanya mengandalkan analisis visual. Untuk mendapatkan kepastian perlu uji hipotesis yaitu menggunakan uji Glejser. Uji Glejser mengusulkan untuk meregres nilai absolud residual (UbsUt) sebagai variabel dependen dengan persamaan sebagai berikut: UbsUt $=\mathrm{a}+\mathrm{bXt}+\mathrm{vi}$

Jika variabel independen secara signifikan mempengaruhi UbsUt maka ada indikasi heteroskedastisitas, sebaliknya jika variabel independen tidak mempengaruhi UbsUt maka tidak ada indikasi heteroskedastisitas. Adapun pengambilan keputusan dan interprestasi adalah sebagai berikut:

- Jika Sig di atas 0,05 maka Ho diterima

- Jika Sig di bawah 0,05 maka Ho ditolak (Tutorial Penelitian, 2015).

\section{Uji Hipotesis}

\section{Uji Signifikansi Secara Parsial (T-Test)}

Uji $t$ digunakan untuk menguji pengaruh variabel independen secara parsial terhadap variabel dependen, yaitu pengaruh dari masing-masing variabel independen yang terdiri atas perputaran piutang, perputaran persediaan, dan solvabilitas terhadap laba per lembar saham yang merupakan variabel dependennya. Seperti halnya dengan uji hipotesis secara simultan, pengambilan keputusan uji hipotesis secara parsial juga di dasarkan pada nilai probabilitas yang didapatkan dari hasil pengolahan data melalui program SPSS statistic parametric sebagai berikut:

- Jika probabilitas >0,5 maka H0 diterima

- Jika probabilitas < 0,5 maka H0 ditolak

Pada uji t, nilai probabilitas dapat dilihat pada hasil pengolahan dari program SPSS pada tabel coefficients 
kolom sig atau significance (Santoso (2004) dalam Ahmad, Murni, \& Mandagie (2014)).

\section{Uji Signifikansi Secara Simultan (F-Test)}

Uji $F$ digunakan untuk menguji pengaruh variabel independen secara bersama-sama terhadap variabel dependen dari suatu persamaan regresi dengan menggunakan hipotesis statistic. Pengambilan keputusan didasarkan pada nilai probabilitas yang didapatkan dari hasil pengolahan data melalui program SPSS statistk parametrik sebagai berikut :

- jika probabilitas > 0,5 maka $\mathrm{H} 0$ diterima

- jika probabilitas < 0,5 maka H0 ditolak

Nilai probabilitas dari uji $\mathrm{F}$ dapat dilihat pada hasil pengolahan dari program SPSS pada tabel ANOVA kolom sig atau significance (Santoso (2004) dalam Ahmad, Murni, \& Mandagie (2014)).

\section{Operasionalisasi Variabel}

Tabel 1

Operasionalisasi Variabel

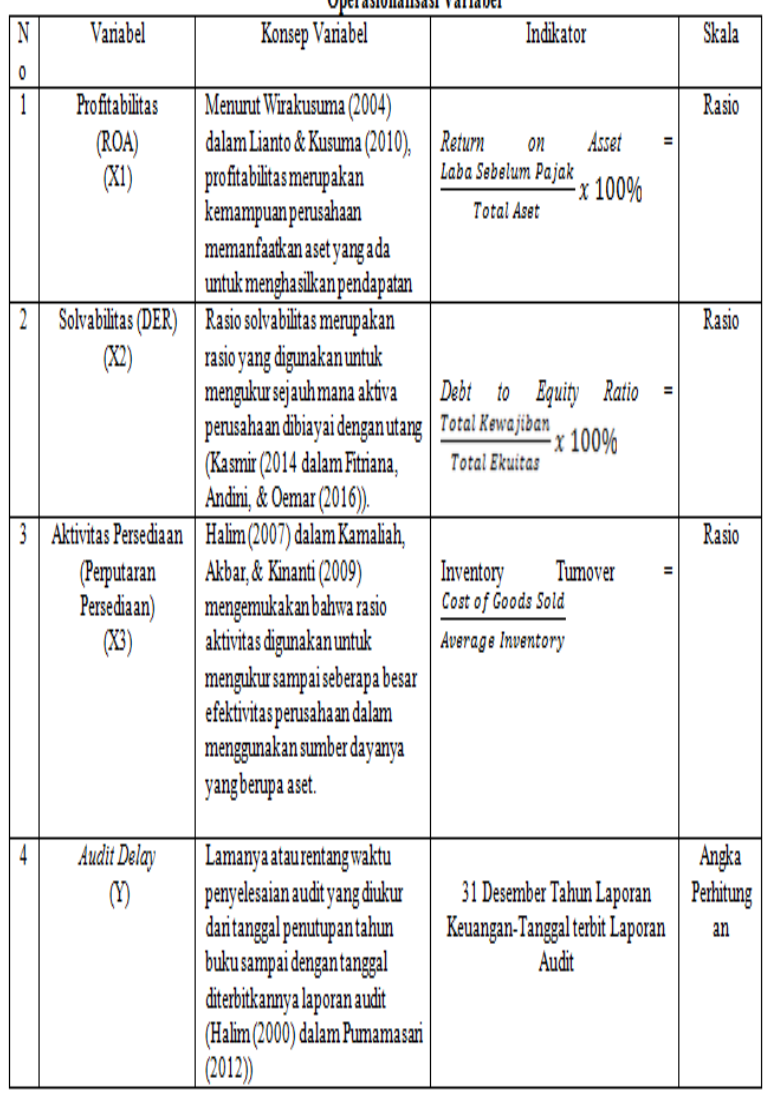

\section{Hasil Penelitian dan Pembahasan}

\section{Gambaran Objek Studi}

Objek studi penelitian ini terdiri atas perusahaanperusahaan retail modern yang terdaftar di Bursa Efek Indonesia yang menjual customer goods atau barangbarang kebutuhan konsumen sehari-hari dari tahun 2014-2015.
Peneliti menganalisis mengenai Audit Delay, dimana penelitian dilakukan untuk meneliti apakah Audit Delay dapat dipengaruhi oleh Profitabilitas (ROA), Solvabilitas (DER), dan Perputaran Persediaan (PP).

\section{Analisis Deskriptif Data Penelitian}

Berdasarkan penelitian yang telah dilakukan, maka dapat dijelaskan deskripsi variabel yang digunakan dalam penelitian ini. Deskripsi ini didasarkan pada indikator yang telah ditentukan dari parameter teori sebagai standar pengukuran. Sebelum dilakukan pengujian statistik mengenai pengaruh ROA, DER, dan PP terhadap Audit Delay baik secara parsial maupun secara simultan, peneliti menyajikan terlebih dahulu deskripsi data dari masing-masing variabel sebagai berikut:

Tabel 2

Hasil Uji Deskriptif

Descriptive Statistics

\begin{tabular}{|c|c|c|c|c|c|}
\hline & $\mathrm{N}$ & $\underset{\mathrm{m}}{\text { Minimu }}$ & $\underset{\mathrm{m}}{\text { Maximu }}$ & Mean & $\begin{array}{c}\text { Std. } \\
\text { Deviati } \\
\text { on }\end{array}$ \\
\hline ROA & $\begin{array}{l}3 \\
0\end{array}$ & -68.00 & 45.80 & 3.5987 & 18.2063 \\
\hline DER & $\begin{array}{l}3 \\
0\end{array}$ & -1.40 & 93.60 & $\begin{array}{r}12.055 \\
7\end{array}$ & 26.2192 \\
\hline PP & $\begin{array}{l}3 \\
0\end{array}$ & .00 & 456.28 & $\begin{array}{r}38.077 \\
0\end{array}$ & $\begin{array}{r}99.7170 \\
1\end{array}$ \\
\hline $\mathrm{AD}$ & 3 & 46.00 & 90.00 & 72.833 & 12.7362 \\
\hline $\begin{array}{l}\text { Valid N } \\
\text { (listwis } \\
\text { e) }\end{array}$ & $\begin{array}{l}3 \\
0\end{array}$ & & & & \\
\hline
\end{tabular}

Berdasarkan tabel, variabel ROA memiliki mean (rata-rata) sebesar 3,5987 dengan standar deviasi 18,20631, nilai terbesar 45,80 dan nilai terkecil $-68,00$.

Berdasarkan tabel, variabel DER memiliki mean (rata-rata) sebesar 12,0557 dengan standar deviasi 26,21923, nilai terbesar 93,60 dan nilai terkecil $-1,40$.

Variabel PP memiliki mean (rata-rata) sebesar 38,0770 dengan standar deviasi 99,71701, nilai terbesar 456,28 dan nilai terkecil 0,00.

Variabel Audit Delay memiliki mean (ratarata) sebesar 72,8333 dengan standar deviasi 12,73627, nilai terbesar 90,00 dan nilai terkecil 46,00.

\section{Uji Asumsi Klasik}

Uji Normalitas 
Tabel 3

Hasil Uji Normalitas

One-Sample Kolmogorov-Smirnov Test

\begin{tabular}{|c|c|c|}
\hline & & $\begin{array}{c}\text { Unstandardized } \\
\text { Residual }\end{array}$ \\
\hline $\begin{array}{l}\mathrm{N} \\
\text { Normal } \\
\text { Parameters }\end{array}$ & $\begin{array}{l}\text { Mean } \\
\text { Std. } \\
\text { Deviation } \\
\text { Absolute } \\
\text { Positive } \\
\text { Negative } \\
\text { v Z }\end{array}$ & $\begin{array}{r}30 \\
0 \mathrm{E}-7 \\
12.17043956 \\
.155 \\
.091 \\
-.155 \\
.851 \\
.463\end{array}$ \\
\hline
\end{tabular}

a. Test distribution is Normal.

b. Calculated from data.

Inteprestasi dari hasil pengujian (dilihat dari nilai sig), data memiliki distribusi normal, karena semua variabel memiliki nilai sig di atas 0,05, dimana nilai sig adalah sebesar 0,463 .

Uji Multikolinearitas

Tabel 4

Hasil Uji Multikolinearitas

\begin{tabular}{|c|c|c|}
\hline \multicolumn{3}{|c|}{ Collinearity Statistics } \\
\hline Model & Tolerance & VIF \\
\hline ROA & .586 & 1.706 \\
\hline DER & .974 & 1.027 \\
\hline PP & .575 & 1.740 \\
\hline
\end{tabular}

Semua variabel bebas terbebas dari multikolinearitas karena semua variabel bebas memiliki nilai tolerance di atas 0,1 dan VIF di bawah 10, dimana nilai tolerance ROA adalah sebesar 0,586, nilai tolerance DER adalah sebesar 0,974 , dan nilai tolerance PP adalah sebesar 0,575. Sedangkan nilai VIF ROA adalah sebesar 1,706, nilai VIF DER adalah 1,027, dan nilai VIF PP adalah sebesar 1,740.

\section{Uji Autokorelasi}

Tabel 5

\section{Hasil Uji Autokorelasi}

Model Summary ${ }^{\mathrm{b}}$

\begin{tabular}{|l|c|c|c|c|c|}
\hline $\begin{array}{l}\text { Mode } \\
1\end{array}$ & $\mathrm{R}$ & $\begin{array}{c}\mathrm{R} \\
\text { Squar } \\
\mathrm{e}\end{array}$ & $\begin{array}{c}\text { Adjuste } \\
\mathrm{d} \mathrm{R} \\
\text { Square }\end{array}$ & $\begin{array}{c}\text { Std. } \\
\text { Error of } \\
\text { the } \\
\text { Estimat } \\
\mathrm{e}\end{array}$ & $\begin{array}{c}\text { Durbin } \\
-\end{array}$ \\
\hline 1 & $\begin{array}{r}.423 \\
\mathrm{a}\end{array}$ & .179 & .084 & 6.39722 & 1.931 \\
\hline
\end{tabular}

a. Predictors: (Constant), PP, DER, ROA

b. Dependent Variable: AD
Dengan nilai $\mathrm{n}=30$ nilai du sebesar 1,6498 , dan nilai 4-du $=4-1,6498=2,3502$ dapat disimpulkan bahwa model tidak terkena auto korelasi, karena nilai Durbin-Watson sebesar 1,931, yang berarti diantara nilai 1,6589 dan 2,3502 .

\section{Uji Heteroskedastisitas}

Tabel 6

Hasil Uji Heteroskedastisitas

\begin{tabular}{|c|c|}
\hline Model & Sig \\
\hline ROA & .062 \\
\hline DER & .518 \\
\hline PP & .749 \\
\hline
\end{tabular}

Dengan nilai sig ROA sebesar 0,062, nilai sig DER sebesar 0,518, dan nilai sig PP sebesar 0,749 dapat disimpulkan bahwa tidak terjadi heteroskedastisitas karena semua variabel memiliki nilai sig di atas 0,05 .

Simpulan dari uji asumsi klasik yang dilakukan pada data penelitian ini adalah data yang diteliti berdistribusi normal, terbebas dari autokorelasi, terbebas dari multikolinearitas, dan terbebas dari heteroskedastisitas.

Selanjutnya dilakukan analisis regresi linear berganda untuk mengetahui apakah terdapat pengaruh baik secara parsial maupun simultan variabel Return on Assets (ROA), Debt to Equity Ratio (DER), dan Perputaran Persediaan (PP) terhadap Audit Delay perusahaan Retail perioda 2014-2015.

\section{Hasil Penelitian}

Uji Signifikansi Secara Parsial (T-Test)

Tabel 7

Hasil Uji T

\begin{tabular}{|c|c|c|}
\hline \multicolumn{3}{|c|}{ Collinearity Statistics } \\
\hline Model & T & sig \\
\hline (Constant) & 22.771 & .000 \\
\hline ROA & -.604 & .551 \\
\hline DER & .202 & .842 \\
\hline PP & .725 & .475 \\
\hline
\end{tabular}

\section{Pengaruh ROA terhadap Audit Delay}

Berdasarkan hasil perhitungan dengan menggunakan SPSS, diperoleh nilai t sebesar -0,604, dengan nilai sig sebesar 0,551, dimana nilai sig lebih besar dari 0,05 . Sehingga dapat disimpulkan, bahwa variabel bebas ROA secara parsial tidak berpengaruh signifikan terhadap variabel terikat (Audit Delay).

\section{Pengaruh DER terhadap Audit Delay}


Berdasarkan hasil perhitungan dengan menggunakan SPSS, diperoleh nilai t sebesar 0,202, dengan nilai sig sebesar 0,842 dimana nilai sig lebih besar dari 0,05. Sehingga dapat disimpulkan, bahwa variabel bebas DER, secara parsial tidak berpengaruh signifikan terhadap variabel terikat (Audit Delay).

\section{Pengaruh PP terhadap Audit Delay}

Berdasarkan hasil perhitungan dengan menggunakan SPSS, diperoleh nilai t sebesar 0,725 , dengan nilai sig sebesar 0,475, dimana nilai sig lebih kecil dari 0,05. Sehingga dapat disimpulkan, bahwa variabel bebas PP, secara parsial tidak berpengaruh signifikan terhadap variabel terikat (Audit Delay).

\section{Uji Signifikansi Secara Simultan (F-Test)}

Tabel 8

Hasil Uji F

ANOVA $^{\mathrm{a}}$

\begin{tabular}{|l|r|r|c|c|c|}
\hline Model & $\begin{array}{c}\text { Sum of } \\
\text { Squares }\end{array}$ & df & $\begin{array}{c}\text { Mean } \\
\text { Square }\end{array}$ & F & Sig. \\
\hline Regression & 408.698 & 3 & 136.233 & .825 & $.492^{\mathrm{b}}$ \\
1 Residual & 4295.468 & 26 & 165.210 & & \\
$\quad$ Total & 4704.167 & 29 & & & \\
\hline
\end{tabular}

a. Dependent Variable: AD

b. Predictors: (Constant), PP, DER, ROA

Berdasarkan hasil perhitungan dengan menggunakan SPSS, diperoleh nilai $F$ sebesar 0.825 , dengan nilai sig sebesar 0,492, dimana nilai sig lebih besar dari 0,05 . Sehingga dapat disimpulkan, bahwa variabel bebas (ROA, DER, dan PP), secara simultan tidak berpengaruh terhadap variabel terikat (Audit Delay).

\section{Dari hasil pengujian secara parsial didapatkan hasil sebagai berikut:}

1. $\mathrm{H}_{1}$ : Pengaruh ROA terhadap Audit Delay $\mathrm{H}_{1}$ : Profitabilitas berpengaruh terhadap Audit Delay pada perusahaan Retail yang terdaftar di Bursa Efek Indonesia tahun 2014-2015 ditolak

2. $\mathrm{H}_{2}$ : Pengaruh DER terhadap Audit Delay $\mathrm{H}_{2:}$ Solvabilitas berpengaruh terhadap Audit Delay pada perusahaan Retail yang terdaftar di Bursa Efek Indonesia tahun 2014-2015 ditolak

3. $\mathrm{H}_{3}$ :Pengaruh PP terhadap Audit Delay $\mathrm{H}_{3}$ : Aktivitas Persediaan berpengaruh terhadap Audit Delay pada perusahaan Retail yang terdaftar di Bursa Efek Indonesia tahun 2014-2015 ditolak
Dari hasil pengujian secara simultan didapatkan hasil sebagai berikut:

4. $\mathrm{H}_{4}$ :Pengaruh ROA, DER dan PP terhadap Audit Delay

$\mathrm{H}_{4}$ : Profitabilitas, Solvabilitas, dan Aktivitas Persediaan berpengaruh Audit Delay pada perusahaan Retail yang terdaftar di Bursa Efek Indonesia tahun 2014-2015 ditolak

\section{Pembahasan Hasil Penelitian}

\section{Pengaruh Return On Assets (ROA) terhadap Audit Delay}

ROA tidak berpengaruh terhadap Audit Delay. Hal tersebut sesuai dengan penelitian yang dilakukan oleh, Susilawati, Agustina \& Prameswari (2012) yang menyatakan bahwa profitabilitas tidak berpengaruh terhadap Audit delay. Hal ini disebabkan banyak perusahaan yang mengalami kenaikan profit namun kenaikan itu tidak begitu besar, apalagi terdapat perusahaan yang mengalami kerugian. Selain itu mungkin tuntutan pihak-pihak yang berkepentingan tidak begitu besar sehingga tidak memicu perusahaan untuk mengkomunikasikan laporan keuangan yang diaudit lebih cepat.

\section{Pengaruh Debt to Equity Ratio (DER) terhadap Audit Delay}

DER tidak berpengaruh terhadap Audit Delay. Hal tersebut sesuai dengan hasil penelitian yang dilakukan oleh Yuliyanti (2011) yang menyatakan bahwa solvabilitas tidak berpengaruh terhadap Audit delay. Hal ini dikarenakan baik perusahaan yang memiliki total utang besar dengan jumlah debtholder yang banyak atau perusahaan yang memiliki total hutang yang kecil dengan jumlah debtholder yang sedikit tidak akan mempengaruhi proses penyelesaian audit laporan keuangan, karena auditor yang ditunjuk pasti telah menyediakan waktu sesuai dengan kebutuhan jangka waktu untuk menyelesaikan proses pengauditan utang (Trianto (2006) dalam Yuliyanti, (2011)).

\section{Pengaruh Perputaran Persediaan (PP) terhadap Audit Delay}

Perputaran Persediaan tidak berpengaruh terhadap Audit Delay. Hal tersebut sesuai dengan hasil penelitian Ramadhan (2012) yang menyatakan bahwa rasio aktivitas tidak berpengaruh terhadap Audit delay, dikarenakan perusahaan belum mampu memutar aktivanya secara efektif. 


\section{Simpulan dan Saran}

\section{Simpulan}

Berdasarkan hasil penelitian yang telah dilakukan ,dapat diperoleh kesimpulan sebagai berikut:

1. Profitabilitas tidak berpengaruh terhadap Audit Delay pada perusahaan Retail yang terdaftar di Bursa Efek Indonesia tahun 2014-2015.

2. Solvabilitas tidak berpengaruh terhadap Audit Delay pada perusahaan Retail yang terdaftar di Bursa Efek Indonesia tahun 2014-2015.

3. Aktivitas Persediaan tidak berpengaruh terhadap Audit Delay pada perusahaan Retail yang terdaftar di Bursa Efek Indonesia tahun 2014-2015.

4. Profitabilitas, Solvabilitas, dan Aktivitas Persediaan tidak berpengaruh terhadap Audit Delay pada perusahaan Retail yang terdaftar di Bursa Efek Indonesia tahun 2014-2015.

\section{Saran}

Berdasarkan hasil penelitian yang telah dilakukan, maka penulis memberikan saran sebagai berikut:

1. Sampel yang digunakan pada penelitian ini hanya perusahaan di sub sektor eceran (retail), maka pada penelitian selanjutnya disarankan untuk memperluas cakupan penelitian ke sektor-sektor dan sub sektorsub sektor perusahaan lainnya.

2. Perusahaan sebaiknya semakin mengurangi Audit Delay-nya, agar dapat lebih cepat menyampaikan informasi terkait laporan keuangan perusahaannya kepada pihak-pihak yang berkepentingan.

3. Penelitian ini hanya meneliti keadaan perusahaan dalam rentang waktu 2 tahun (2014-2015), sehingga peneliti selanjutnya dapat menambah rentang waktu penelitian sehingga mendapatkan hasil yang lebih akurat dan representatif.

4. Variabel bebas yang digunakan di penelitian ini hanya terbatas pada profitabilitas (ROA), Solvabilitas (DER), dan Aktivitas Persediaan (PP) ,sehingga disarankan pada peneliti selanjutnya untuk menambahkan variabel lainnya sebagai prediktor dalam memprediksi Audit Delay.

\section{Daftar Pustaka}

Accounting Media. (2014). Data Primer dan Data Sekunder. Diakses pada 19 Juli, 2016, dari http://accountingmedia.blogspot.co.id/2014/06/data-primer-dandata-sekunder.html
Ahmad, Fadliyan; Murni, Sri \& Yunita Mandagie. 2014. Perputaran Piutang, Perputaran Persediaan, dan Struktur Modal Terhadap Laba Per Lembar Saham Pada Industri Semen Yang Go Public di BEI, Jurnal EMBA. Vol. 2 (No. 2) hal. 1559-1569.

Agustina, Lidya dan Aldie, Rangga Reza. 2013. Faktor-Faktor yang Berpengaruh terhadap Audit Delay (Studi Empiris pada Perusahaan Manufaktur yang Terdaftar di Bursa Efek Indonesia Tahun 2008). Jurnal Akurat: Jurnal Ilmiah Akuntansi. Vol. 4 (No.11), hal. 14-37.

Fitriana, Dewi; Andini, Rita; \& Oemar, Abrar. 2016. Pengaruh Likuiditas, Solvabilitas, Profitabilitas, Aktivitas dan Kebijakan Deviden terhadap Return Saham Perusahaan Pertambangan yang Terdaftar pada BEI Periode 2007-2013. Journal of Accounting. Vol. 2 (No.2), hal. 10-23.

Hafis, Al. 2016. Pengaruh Perputaran Persediaan dan Perputaran Piutang terhadap Profitabilitas pada PT Kimia Farma Persero (Tbk). Skripsi, Pekanbaru: Program Studi S1-Manajemen Universitas Islam Negeri Sultan Syarif Kasim Riau.

Kamaliah; Akbar, Nasriza;, \& Kinanti, Lexinta. 2009. Analisis Pengaruh Rasio Aktivitas, Leverage Keuangan, Ukuran, dan Umur Perusahaan terhadap Profitabilitas Perusahaan Wholesale dan Retail Trade yang Terdaftar di Bursa Efek Indonesia. Jurnal Ekonomi. Vol. 17 (No.3), hal. 10-23.

Kartika, Andi. 2009. Faktor-Faktor yang Mempengaruhi Audit Delay di Indonesia (Studi Empiris pada Perusahaan-perusahaan LQ 45 yang Terdaftar di Bursa Efek Jakarta). Jurnal. Vol. 16 (No.1), hal. 1-17.

Kusuma, Dewi; Arifati, Rina; \& Andini Rita. 2014. Pengaruh Perputaran Piutang, Perputaran Persediaan dan Tingkat Likuiditas terhadap Profitabilitas Perusahaan Manufaktur yang Terdaftar di BEI . Jurnal SOSIOEKOTEKNO (Jurnal Ilmiah Mahasiswa Universitas Pandanaran Semarang). Diakses dari http://st293545.sitekno.com/article/135446/pen garuh-perputaran-piutang-perputaranpersediaan-dan-tingkat-likuiditas-terhadapprofitabilitas-perusahaan-manufaktur-yangterdaftar-di-bei.html

Lianto, Novice, dan Kusuma, Budi Hartono. 2010. Faktor-Faktor yang Berpengaruh pada Audit Report Lag. Jurnal Bisnis dan Akuntansi. Vol. 12 (No.2), hal. 97-106.

Maharani, Angelia. (2015). Melakukan Sampling Dengan Metode Judgement. Diakses pada 19 Juli, 2016, dari http://angeliamaharanisetyaputri.blogspot.co.id /2015/02/melakukan-sampling-denganmetode.html 
Pratama, Baradha. 2014. Analisis faktor-faktor yang Mempengaruhi Audit Delay dan Timeliness pada Perusahaan Publik di Indonesia. Skripsi, Semarang: Program Studi S1-Akuntansi Universitas Diponegoro

Purnamasari, Carmelia Putri 2012. Analisis FaktorFaktor yang Mempengaruhi Audit Delay pada Perusahaan LQ 45 yang Terdaftar di Bursa Efek Indonesia. Publikasi, Fakultas Ekonomi Universitas Gunadarma.

Ramadhan, Wibisana. 2012. Analisis Faktor-Faktor yang Mempengaruhi Audit Delay (Studi Empiris pada Perusahaan Manufaktur yang Terdaftar di Daftar Efek Syariah Tahun 20082010. Skripsi, Yogyakarta: Program Studi S1Keuangan Islam, Universitas Islam Negeri Sunan Kalijaga.

Rizki M., Rezwan. (2014). Karakteristik Kualitatif Laporan Keuangan. Diakses pada 16 Mei, 2016, dari http://rezwanrizki.blogspot.co.id/2014/01/karakteristikkualitatif-laporan.html

Setyaningsih, Yulia Vivian. 2014. Analisis FaktorFaktor yang Mempengaruhi Audit Delay: Studi Empiris pada Perusahaan Go Public yang Mengalami Keterlambatan Dalam Penyampaian Laporan Keuangan Auditan Tahun 2012. Skripsi, Bandung: Program Studi S1-Akuntansi Universitas Kristen Maranatha

Simbolon, Kartika P. 2009. Analisis Faktor-Faktor yang Mempengaruhi Audit Delay pada Perusahaan yang Terdaftar di Bursa Efek Indonesia. Skripsi, Medan: Program Studi S1Akuntansi Universitas Sumatera Utara.

Sinurat, Parulian. 2014. Analisis Faktor-Faktor yang Mempengaruhi Audit Delay pada Perusahaan Otomotif yang Terdaftar di Bursa Efek Indonesia. Skripsi, Medan: Program Studi S1Akuntansi Universitas Sumatera Utara.

Susilawati, Christine Dwi Karya; Agustina, Lidya; \& Prameswari, Tania. 2012. Analisis FaktorFaktor yang Mempengaruhi Terjadinya Audit Delay pada Perusahaan Consumer Good Industry di Bursa Efek Indonesia (Periode Tahun 2008-2010). Jurnal Akurat: Jurnal Ilmiah Akuntansi. No.10, hal. 19-30.

Tutorial Penelitian. (2015). Tutorial Olah Data SPSS: Tes Heterokedastisitas Menggunakan Uji Glejser.. Diakses pada 19 Juli, 2016, dari http://tu.laporanpenelitian.com/2015/07/14. html

UCEO (Universitas Ciputra Entrepreneurship Online). (2016). Metode Pengumpulan Data Dalam Penelitian. Diakses pada 19 Juli, 2016, dari http://www.ciputrauceo.net/blog/2016/2/18/metode-pengumpulandata-dalam-penelitian
Wijaya, Wira. (2013). Penelitian Eksplanatori. Diakses pada 19 Juli, 2016, dari http://kutukuliah.blogspot.co.id/2013/05/penge rtian-penelitian-eksplanatori-adalah.html

Yuliyanti, Ani. 2011. Faktor-faktor yang

Berpengaruh terhadap Audit Delay (Studi Empiris pada Perusahaan Manufaktur yang Terdaftar di Bursa Efek Indonesia pada Tahun 2007-2008). Skripsi, Yogyakarta: Program Studi S1-Akuntansi Universitas Negeri Yogyakarta. 